DOI: https://doi.org/10.15407/techned2020.05.065

\title{
NEW APPROACH TO SIMULATION OF EXTRA-POWER SOLAR PLANT WITH POWER EVACUATION BY NETWORKS OF THE CHERNOBYL NPP
}

Journal

Publisher

ISSN

Issue

Pages
Tekhnichna elektrodynamika

Institute of Electrodynamics National Academy of Science of Ukraine 1607-7970 (print), 2218-1903 (online)

No 5, 2020 (September/October)

$65-69$

\section{Authors}

L. Lukianenko*, A. Steliuk*

Institute of Electrodynamics, National Academy of Sciences of Ukraine,

Peremohy Ave., 56, Kyiv, 03057, Ukraine,

e-mail: lukianenko.lukian@gmail.com

* ORCID ID : https://orcid.org/0000-0003-1749-5209

** ORCID ID : https://orcid.org/0000-0001-7548-4757

\begin{abstract}
This paper deals with the system study for the development and connection of $1200 \mathrm{MWp}$ Chernobyl photovoltaic (PV) plant to the transmission grid of interconnected power system of Ukraine. The aim of this study is to develop the planetary models of solar power plant, to perform quasi-dynamic simulation and to check network steady-state operating conditions at peak production of the PV plant, including identification of the element loadings in the transmission and distribution networks, bus voltages in the area, fulfillment of the grid code requirements. References 5 , figures 5 .
\end{abstract}

Key words: extra-power solar plant, Chernobyl nuclear power plant (NPP), power evacuation, quasi-dynamic simulation, solar irradiation, voltage, equipment loading. 
Accepted: 12.05 .2020

Published: 25.08.2020

\section{References}

1. Gottardo L. PV and Storage systems Management. Analysis of Self-Consumption strategies for Italian and Spanish Householders. Tesi di Laurea Magistrale. Università Degli Studi Di Padova, 2016. URL: http://tesi.cab.unipd.it/51578/1/Gottardo_Laura_1080818.pdf (accessed 15.12.2019)

2. Nalis A. Quasi-Dynamic Characterization of Hybrid Photovoltaic/Thermal (PV/T) Flat-Plate Collectors, Ph.D. Degree Dissertation Thesis. Universitat de Lleida, 2012. URL: http://hdl.handl e.net $/ 10803 / 84100$ (accessed 05.12.2019)

3. Report on Yield Assessment of the Photovoltaic Power Plant, pvPlanner, Solargis s.r.o., 2017 4. CAMS Radiation Service, 2017.URL: http://www.soda-pro.com/web-services/radiation/cams -radiation-service (accessed 15.01.2020)

5. Atmospheric Science Data Center, 2017. URL: https://eosweb.larc.nasa.gov/ (accessed 15.01.2020)

$\underline{\text { PDF }}$

This work is licensed under a Creative Commons Attribution-NonCommercial-NoDerivatives 4.0 International License 